\section{ASSESSING DEFICIT IRRIGATION STRATEGIES FOR CORN USING SIMULATION}

\author{
I. Kisekka, J. P. Aguilar, D. H. Rogers, J. Holman, \\ D. M. O’Brien, N. Klocke
}

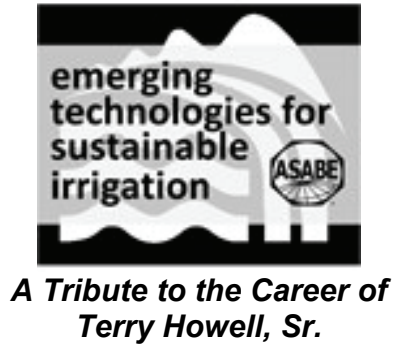

\begin{abstract}
Declining groundwater levels in the Ogallala aquifer due to withdrawals exceeding annual recharge result in diminished well capacities that eventually become incapable of meeting full crop water needs. Producers need recommendations for deficit irrigation strategies that can maximize net returns in most years under low well capacities. The objectives of this study were to (1) calibrate and validate the CERES-Maize model in DSSAT-CSM v4.6 under southwest Kansas soils and climatic conditions and (2) apply the calibrated model to assess three factors related to irrigation management: (i) the optimum plant-available water threshold to initiate irrigation for maximizing net returns, (ii) the effect of percentage soil water depletion at planting on yield, seasonal transpiration, water productivity, extractable soil water at maturity, and net returns, and (iii) the effect of late irrigation season termination on extractable soil water at physiological maturity, yield, and net returns. The CERES-Maize model in DSSAT-CSM v4.6 in conjunction with short-term experimental data and 63 years (1950 to 2013) of historical weather data were used in this study. The calibrated model was able to predict end of season grain yield with acceptable accuracy (NSE $>0.9,0.13<\% R M S E<0.19$ ), indicating that the model could be used for assessing alternative management strategies for optimizing the use of limited water for irrigating corn in southwest Kansas. Irrigation scheduling based on a 50\% plant-available water threshold maximized net returns compared to initiating irrigation at greater soil water content at corn prices ranging from $\$ 0.10$ to $\$ 0.26 \mathrm{~kg}^{-1}$. Accounting for inter-annual variations in weather and irrigation downtime due to repairs, 14 to 17 irrigation applications of $25 \mathrm{~mm}$ of water each would be needed to maintain soil water at $50 \%$ of plant-available water during the season. Having soil water in the top $1.2 \mathrm{~m}$ of the soil profile between $0 \%$ and $25 \%$ depleted at planting maximized net returns, although it also resulted in more extractable soil water at physiological maturity. Terminating irrigation 90 or 95 days after planting depending on corn price maximized net returns and resulted in the lowest amount of extractable soil water at physiological maturity, implying that opportunities exist to mine stored soil water toward the end of the season even under deficit irrigation. We recommend that late season irrigation termination be done in conjunction with soil water monitoring and management-allowable depletion techniques to minimize potential reduction in yields. Before adopting any of the management strategies assessed in this study, producers should consider the unique yield potential constraints for their farm. The concepts explored in this analysis, which combined experimental data, computer simulation, and long-term weather data to generate optimum management recommendations, could be applied in other areas with constrained water supplies for irrigation.
\end{abstract}

Keywords. Corn, Crop modeling, Deficit irrigation, Water limited, Water productivity.

Submitted for review in February 2015 as manuscript number NRES 11206; approved for publication by the Natural Resources \& Environmental Systems Community of ASABE in May 2015. Station.

Contribution No. 15-255-J from the Kansas Agricultural Experiment

The authors are Isaya Kisekka, ASABE Member, Assistant Professor, and Jonathan Aguilar, ASABE Member, Assistant Professor, Kansas State University Southwest Research and Education Center (SWREC), Garden City, Kansas; Danny Rogers, ASABE Fellow, Professor, Department of Biological and Agricultural Engineering, Kansas State University, Manhattan, Kansas; Johnathon Holman, Associate Professor, Kansas State University SWREC, Garden City, Kansas; Dan O'Brien, Associate Professor and Agricultural Economist, Kansas State University Northwest Research and Education Center (NWREC), Colby Kansas; Norman Klocke, ASABE Member, Professor Emeritus, Kansas State University SWREC, Garden City, Kansas. Corresponding author: Isaya Kisekka, SWREC, 4500 E. Mary St., Garden City KS 67846; phone: 620-276-8286; e-mail: ikisekka@ksu.edu.

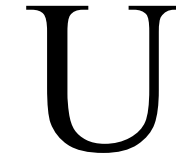

nsustainable withdrawal of water for irrigation has resulted in depletion of the Ogallala aquifer at varying levels over much of its spatial extent. The southern and central High Plains regions, including western Kansas, eastern Colorado, and the Panhandles of Texas and Oklahoma, have experienced the steepest declines (McGuire, 2012). A top priority is to improve irrigation water management for corn because corn is the most widely irrigated crop in the region. Corn is an important crop for the livestock feeding industry in this region, which accounts for $36 \%$ of the total fed cattle in the U.S. (Guerrero et al., 2013). By maintaining profitable corn production, the important livestock industry in the region can also be maintained.

When well capacity is diminished and cannot meet full corn water needs, limited or deficit irrigation management strategies that maximize economic returns per unit of water 
applied need to be considered. Lamm et al. (1996) reviewed several irrigation macromanagement strategies for corn, such as timing for initiation and termination of the irrigation season, and the need for preseason irrigation. They reported that the advantages of in-season irrigation scheduling using evapotranspiration (ET) based water balance or soil water monitoring could be greatly reduced by inappropriate macromanagement. For example, they recommended that the decision to terminate seasonal irrigation should be determined from the anticipated soil water at physiological maturity (estimated from ET based water balance or soil water measurements) and target management allowable depletion (MAD) at maturity. Although early termination of the irrigation season could promote use of previously stored soil water, inappropriate early termination could reduce corn yields. Similarly, they indicated that late initiation of the irrigation season might not be prudent for low-capacity well systems, and in some cases spring preseason irrigation to increase soil water at planting may be profitable.

Ensuring sufficient soil water at planting can be achieved through enhanced capture of erratic winter precipitation or spring preseason irrigation. The practice of preseason irrigation to increase soil water at planting in deep silt loam soils of western Kansas was reviewed by several investigators (Rogers and Lamm, 1994; Stone and Schlegel, 2006; Schlegel et al., 2011). Based on a survey of producers' fields, Rogers and Lamm (1994) reported that additional water beyond that required to bring soil water in the profile to $50 \%$ of maximum available water had a greater probability of being ineffective; therefore, preseason irrigation was not a recommended practice for corn in the region except in very dry years that are difficult to predict ahead of time. Stone and Schlegel (2006) reviewed approaches and practices for effective use of water in limited irrigation environments; they concluded that preseason irrigation in the spring was a relatively efficient use of water on deep silt loam soils of western Kansas if available soil water was less than $60 \%$ of maximum available soil water. They also showed that preseason irrigation beyond $70 \%$ of maximum available soil water resulted in increased water losses and reduced storage of winter precipitation and resulted in negligible yield benefit. Schlegel et al. (2011) reported that preseason irrigation was profitable at low well capacities for corn, but reduced winter soil water storage occurred as well capacities were increased. Musick and Lamm (1990) listed situations in which preseason irrigation may be advantageous and where it may not be the best use of water in the central and southern High Plains.

Schneekloth et al. (2004) discussed several strategies that could be implemented under restricted water supplies, including: reducing irrigated acreage to meet full evapotranspiration (ET) needs while increasing land area under dryland production, reducing the amount of irrigation water applied to the whole field, rotating high water use crops such as corn with winter crops such as wheat, managing the soil water reservoir to capture precipitation through residue management and reduced tillage, timely termination of irrigation toward the end of the season to promote use of previously stored soil water, and delaying irrigation until critical growth stages and implementing irrigation scheduling to optimally apply irrigation water. The challenge is to find a mix of deficit irrigation management strategies that maximize economic returns for the majority of years under erratic climatic conditions, which are common in the High Plains. In developing long-term recommendations that account for interannual climate variations, a useful approach is to combine short-term field experiments with cropping systems models and long-term historical weather data in assessing management strategies.

Several cropping systems models could be used in assessing deficit irrigation management, including DSSATCSM (Jones et al., 2003), WOFOST (Van Diepen et al., 1989), APSIM (Keating et al., 2003), RZWQM (USDAARS, 1992), and AquaCrop (Raes et al., 2009). These models vary in complexity in the way they simulate cropping systems. Crop growth modules within these models can be carbon, radiation, or water driven. Carbon-driven models simulate crop growth based on carbon assimilation by leaves through photosynthesis (e.g., CROPGRO models in DSSAT). Radiation-driven models simulate biomass as a function of radiation use efficiency (e.g., CERES-Maize crop model in DSSAT). Water-driven models simulate biomass growth or yield as linearly proportional to transpiration or ET through a water productivity parameter (e.g., AquaCrop and Kansas Water Budget). Todorovic et al. (2009) compared different types of models and reported that all models predicted yields fairly well under no water stress to moderate stress, but there was general underestimation of yield by all models under severe water stress.

Simulation models of various kinds have previously been used to assess deficit irrigation for corn under limited water supplies in the central Great Plains (Ma et al., 2003; Stone et al., 2006; Lamm et al., 2007; Saseendran et al., 2008; DeJonge et al., 2011, 2012). Ma et al. (2003) used the USDA-ARS Root Zone Water Quality Model (RZWQM) to simulate responses of corn growth and yield to different levels of irrigation in northeastern Colorado and reported that the model sufficiently predicted relative increases in yield with irrigation. Stone et al. (2006) applied a water-driven yield prediction model (Kansas Water Budget) to develop yield vs. water functions for six major irrigated crops in the central High Plains, including corn. Saseendran et al. (2008) calibrated and validated the CERESMaize model for northeastern Colorado and used it to predict optimum allocation of water between vegetative and reproductive growth stages. DeJonge et al. (2011) also used CERES-Maize to predict yield and ET under different levels of deficit irrigation in eastern Colorado. DeJonge et al. (2012) improved simulation of ET in CERES-Maize under limited irrigation.

These studies demonstrate the utility of cropping systems models when combined with experimental data and historical weather records as a robust method for evaluating deficit irrigation strategies under erratic climatic conditions. When locally calibrated and validated, these cropping systems models can be used as decision support tools. For this study, we chose DSSAT-CSM v4.6Beta due to the following reasons: (1) DSSAT-CSM can perform seasonal analysis of long-term response of crop yields to a combina- 
tion of climate, management (e.g., irrigation, fertilization, tillage, etc.), and genetic factors, (2) DSSAT-CSM can perform economic analysis such as net returns and risk analysis, and (3) DSSAT-CSM has utilities that simplify tasks related to data input and output analysis. However, DSSAT-CSM has some disadvantages that are common to many crop models, including absence of algorithms for directly predicting the impact of abiotic stress factors such as weeds, diseases, and hail on yield.

The objectives of this study were to (1) calibrate and validate the CERES-Maize model in DSSAT-CSM v4.6 under southwest Kansas soils and climatic conditions and (2) apply the calibrated model to assess three factors related to irrigation management: (i) the optimum plant-available water threshold to initiate irrigation for maximizing net returns, (ii) the effect of percentage soil water depletion at planting on yield, seasonal transpiration, water productivity, extractable soil water at maturity, and net returns, and (iii) the effect of late irrigation season termination on extractable soil water at physiological maturity, yield, and net returns.

\section{Materials ANd Methods EXPERIMENTAL DATA}

A limited irrigation cropping systems study was conducted at the Kansas State University Southwest ResearchExtension Center Finnup farm ( $38^{\circ} 1^{\prime} 20.87^{\prime \prime} \mathrm{N}, 100^{\circ} 49^{\prime}$ $26.95^{\prime \prime} \mathrm{W}$, elevation of $887 \mathrm{~m}$ above mean sea level) near Garden City, Kansas, from 2005 to 2012; experimental results were reported by Klocke et al. (2011, 2014). The climate of the area is semi-arid. The soil at the study site is a deep well drained Ulysses silt loam (fine-silty, mixed, mesic Aridic Haplustoll). Four crops were grown in a fiveyear rotation of corn-corn-wheat-sorghum-sunflower, and a detailed description of the randomized block experimental design was reported by Klocke et al. (2015). Each of the four crops moved in rotation in five crop blocks each year; therefore, each crop was present every year. For this analysis, we used second-year corn (2009 yields were partly damaged by hail) following corn data for 2010 to calibrate the model, and 2011 and 2012 data were used to validate a DSSAT-CSM v4.6 CERES-Maize model for southwest Kansas. The study had six irrigation treatments designed to mimic water supply limitations in the area where declining groundwater levels in the Ogallala aquifer dictate well capacity, which in turn dictates irrigation frequency and amount. Each irrigation event applied $25 \mathrm{~mm}$ of water to ensure sufficient movement of the water into the soil while minimizing evaporative losses; this practice is commonly used by producers in the area.
Table 1. Total number of irrigation events applied to different deficit irrigation treatments on a 1.1 ha experimental plot in 2010, 2011, and 2012 near Garden City, Kansas.

\begin{tabular}{cccc}
\hline & \multicolumn{3}{c}{ Number of 25 mm Irrigation Events } \\
\cline { 2 - 4 } Irrigation Treatment & 2010 & 2011 & 2012 \\
\hline 1 & 12 & 18 & 19 \\
2 & 9 & 14 & 15 \\
3 & 4 & 10 & 10 \\
4 & 4 & 7 & 8 \\
5 & 4 & 4 & 4 \\
6 & 1 & 2 & 1 \\
\hline
\end{tabular}

The frequency-based irrigation treatments (treatments 1 through 6 in table 1) were designed to irrigate every 4.5, $7.3,9,11,15.7$, and 0 (dryland) days, respectively. The frequency-based irrigation schedule determined at the beginning of the season was not changed in case of a rainfall event. However, if a rainfall event of more than $20 \mathrm{~mm}$ was received, we skipped any irrigation event scheduled for that day. Treatment 1 was managed as a fully irrigated crop with irrigation frequency of 4.5 days coupled with soil water monitoring to ensure that soil water did not drop below $50 \%$ of available water in the top $1.2 \mathrm{~m}$ of the soil profile. Treatment 6 received one or two irrigation applications to ensure crop germination. The total number of irrigations varied by year, as shown in table 1, due to differences in growing season precipitation; for example, 2010 was wetter, with $247 \mathrm{~mm}$ of precipitation, compared to 156 and $157 \mathrm{~mm}$ received in 2011 and 2012, respectively. A fourspan lateral-move sprinkler irrigation system (model 8000, Valmont Corp., Valley, Neb.), modified as described by Klocke et al. (2003) to apply irrigation water in any desired treatment combination, was used. Seeding rates varied across irrigation treatments, as described by Klocke et al. (2014).

\section{MODEL DESCRIPTION}

The CERES-Maize model used in this study to simulate corn development and growth is one of a suite of crop models in DSSAT-CSM v4.6. CERES-Maize is a radiationbased mechanistic crop model that predicts corn growth and development based on weather (precipitation, solar radiation, maximum and minimum temperature, and to a lesser extent photoperiod), six cultivar/genetic coefficients (P1, P2, P5, G2, G3, and PHINT, defined in table 2), and management practices (planting population, row spacing, planting date, and irrigation management). Rate of development is governed by thermal time or growing degree days (GDD), where GDD are computed from maximum and minimum air temperatures. The number of GDD required to progress from one growth stage to another is defined using crop-specific cultivar coefficients (table 2), which are input by the user or calculated by the model using experimental data. The number of GDD on a given cal-

Table 2. Calibrated cultivar coefficients for the CERES-Maize model in DSSAT-CSM v4.6.

\begin{tabular}{|c|c|c|c|}
\hline Cultivar Coefficients & Simulated & Values & Units \\
\hline Thermal time from emergence to end juvenile phase & P1 & 255.00 & Degree days \\
\hline Photoperiod sensitivity coefficient $(0-1.0)$ & $\mathrm{P} 2$ & 0.76 & Days \\
\hline Thermal time from silking to physiological maturity & P5 & 680.00 & Degree days \\
\hline Maximum possible number of kernels per plant & $\mathrm{G} 2$ & 978.40 & Unitless \\
\hline Kernel filling rate during linear grain filling/optimum conditions & G3 & 10.00 & $\mathrm{mg} \mathrm{d}^{-1}$ \\
\hline Phyllochron interval (degree days required for a leaf tip to emerge) & PHINT & 35.90 & Degree days \\
\hline
\end{tabular}


endar day is a function of a trapezoidal curve defined by lower and upper temperatures and two optimum temperatures (Jones et al., 2003). Leaf area expansion in CERESMaize is modified by GDD and by water and nitrogen stresses.

Daily growth is calculated by converting daily intercepted photosynthetically active radiation (PAR) into dry matter using a crop-specific radiation use efficiency parameter (Jones and Kiniry, 1986). Light interception in CERESMaize is computed as a function of leaf area index, plant population, and row spacing, as shown in equation 1:

$$
P C A R B=\frac{R U E \times P A R}{P L T P O P}\left(1-e^{(-k \times L A I)}\right) \times C_{2}
$$

where $P C A R B$ is potential plant growth rate $\left(\mathrm{g}\right.$ plant $\left.{ }^{-1}\right)$; $R U E$ is radiation use efficiency (set to $4.2 \mathrm{~g}$ dry matter $\mathrm{MJ}^{-1}$ PAR in CERES-Maize v4.6); PAR is photosynthetically active radiation $\left(\mathrm{MJ} \mathrm{m}^{-2} \mathrm{~d}^{-1}\right) ; k$ is the light extinction factor, which is a function of row spacing and plant population ( $k$ is located in the MZCER06.ECO file, and a value of 0.85 was used in this study); $L A I$ is leaf area index; and $\mathrm{CO}_{2}$ is the atmospheric $\mathrm{CO}_{2}$ modification factor. Daily dry matter production is modified by water and nitrogen stress, temperature stress, and soil fertility stress. To account for the stress factors on plant growth, equation 1 was modified as expressed in equation 2 :

$$
\begin{aligned}
& C A R B O=P C A R B \\
& \times \min [1,(P R F T, S W F A C, N S T R E S,(1-S A T F A C))] \\
& \times P G F A C 3
\end{aligned}
$$

where $C A R B O$ is daily plant growth $\left(\mathrm{g}_{\text {plant }}{ }^{-1}\right), P R F T$ is the temperature effect $(0,1), S W F A C$ is the water deficit or stress effect, NSTRES is the nitrogen stress effect, SATFAC is the water logging effect, and $P G F A C 3$ is the soil fertility factor obtained from the DSSAT-CSM soils database. The stress effects vary between 0 and 1 , where 1 represents no stress and 0 represents complete stress. Accumulated biomass is partitioned to leaves, stems, roots, and grain as a function of growth stage. Leaf area expansion and senescence are driven by temperature and assimilate availability.

In terms of grain yield, kernels per plant are computed during flowering based on the cultivar's genetic potential, average rate of carbohydrate accumulation during flowering, temperature, and water and nitrogen stresses during flowering. Potential kernels per plant is a user-defined parameter ( $\mathrm{G} 2$ in table 2). Once the grain filling stage is reached, the model computes daily grain growth as a product of CARBO, G3, and grain filling efficiency, which is a function of temperature. Kernels are allowed to grow until physiological maturity is reached. However, if the plant depletes resources such as water and nitrogen, growth is terminated prior to physiological maturity.

Due to the importance of soil water deficit effects on grain yield in this study, a detailed description of how soil water stress affects corn growth in CERES-Maize is warranted. Soil water balance in CERES-Maize is simulated using the DSSAT-CSM tipping-bucket approach (Ritchie, 1998). The Soil Conservation Service runoff curve number was used to calculate daily runoff, and infiltration was cal- culated as the difference between rainfall/irrigation and runoff (SCS, 1972). Two options are available to calculate potential evapotranspiration (E0) in DSSAT-CSM: FAO-56 Penman-Monteith and Priestley-Taylor. We used the latter approach due to the advantage of requiring minimum weather inputs (maximum and minimum temperature and solar radiation). For situations where a complete weather data set is available (solar radiation, temperature, relative humidity, and wind speed), the FAO-56 method would be preferred for estimating $E 0 . E 0$ is partitioned into potential transpiration $\left(E P_{o}\right)$ and potential soil evaporation $\left(E S_{o}\right)$ using equation 3 :

$$
\begin{aligned}
& E P_{o}=E 0[1-\exp (-k \times L A I)] \\
& E S_{o}=E 0-E P_{o}
\end{aligned}
$$

where $k$ is the light extinction coefficient. Ritchie (1998) proposed a soil water variable called the soil-limited root water uptake $\left(E P_{r}\right)$, computed as a function of effective root growth and available water. The actual root water uptake is taken as the smaller of $E P_{r}$ and $E P_{o}$. Based on the ratio of $E P_{r}$ and $E P_{o}$, two stress factors are calculated that effect plant growth. Under well-watered conditions, the ratio of $E P_{r}$ and $E P_{o}$ is greater than 1, but as soil water is depleted due to root water uptake, $E P_{r}$ is reduced until a threshold is reached, at which the turgor stress factor (TURFAC) is triggered, which limits expansive growth (Ritchie, 1998). When $E P_{o}$ exceeds $E P_{r}$, a second stress factor $(S W F A C)$ is triggered, which reduces the rate of photosynthesis. $S W F A C$ is computed as the ratio of $E P_{r}$ and $E P_{o}$ and ranges between 0 and 1 , with 0 being complete water stress and 1 being well watered.

\section{Model Calibration and VAlidation}

To ensure the model performs adequately under full and deficit irrigation, all six irrigation treatments for 2010 were used in model calibration, as suggested by DeJonge et al. (2012). Soil physical and hydraulic properties including saturated water content, upper drain limit, lower drain limit, and bulk density for the Ulysses silt loam were obtained from Klocke et al. (2011) (table 3). The root growth weighting factor (for different soil layers) to a depth of

\begin{tabular}{|c|c|c|c|c|c|}
\hline Soil & Lower & Upper & & $\overline{\text { Bulk }}$ & \\
\hline $\begin{array}{l}\text { Depth } \\
(\mathrm{cm})\end{array}$ & $\begin{array}{c}\text { Limit } \\
\left(\mathrm{cm}^{3} \mathrm{~cm}^{-3}\right)\end{array}$ & $\begin{array}{c}\text { Limit } \\
\left(\mathrm{cm}^{3} \mathrm{~cm}^{-3}\right)\end{array}$ & $\begin{array}{l}\text { Saturation } \\
\left(\mathrm{cm}^{3} \mathrm{~cm}^{-3}\right)\end{array}$ & $\begin{array}{l}\text { Density } \\
\left(\mathrm{g} \mathrm{cm}^{-3}\right)\end{array}$ & $\mathrm{RGWF}^{[\mathrm{a}]}$ \\
\hline $0-5$ & 0.15 & 0.33 & 0.45 & 1.37 & 1.0 \\
\hline $5-15$ & 0.15 & 0.33 & 0.45 & 1.37 & 1.0 \\
\hline $15-30$ & 0.15 & 0.33 & 0.45 & 1.37 & 1.0 \\
\hline $30-45$ & 0.15 & 0.33 & 0.45 & 1.37 & 0.6 \\
\hline $45-60$ & 0.15 & 0.33 & 0.45 & 1.37 & 0.3 \\
\hline $60-90$ & 0.15 & 0.33 & 0.45 & 1.38 & 0.2 \\
\hline $90-120$ & 0.15 & 0.33 & 0.45 & 1.38 & 0.1 \\
\hline $120-150$ & 0.15 & 0.33 & 0.45 & 1.39 & 0.0 \\
\hline $150-170$ & 0.15 & 0.33 & 0.45 & 1.39 & 0.0 \\
\hline $170-190$ & 0.15 & 0.33 & 0.45 & 1.39 & 0.0 \\
\hline $190-210$ & 0.15 & 0.33 & 0.45 & 1.39 & 0.0 \\
\hline
\end{tabular}
$1.2 \mathrm{~m}$ in increments of $10 \mathrm{~cm}$ was adjusted in order to

Table 3. Soil physical properties at the Kansas State University Southwest Research and Extension Center Finnup irrigation research site (Klocke et al., 2011). Lower limit, upper limit, and bulk density were measured in the field.

[a] $\mathrm{RGWF}=$ root growth weighting factor. 
achieve acceptable fit between simulated and measured yield, aboveground biomass, and maximum LAI. The six cultivar/genetic coefficients (table 2) for corn were manually calibrated, and goodness-of-fit statistical measures were used to assess model calibration with Nash-Sutcliffe efficiency (NSE) of $>0.9$ considered acceptable. Cultivar coefficients define life cycle and phase duration such as photothermal days to flowering and maturity, and seed fill; therefore, they need to be determined for a given environment before cropping systems simulation models can be properly applied. Data used for calibration included observed phenology (emergence date, anthesis date, and physiological maturity date), growth data (LAI measured at anthesis), and measured grain yield. Calibration was implemented in two stages: parameters that affect development and life cycle (P1, P2, P5, and PHINT) were adjusted first, followed by parameters that affect growth and yield (G2 and G3). The target variables for model validation were grain yield, endof-season aboveground dry matter, maximum LAI, harvest index, water productivity, and irrigation water use efficiency for six irrigation treatments in 2011 and 2012. The goodness-of-fit statistical measures of model performance used in this study included NSE, root mean square error (RMSE), and relative error. Our target ranges for the goodness-of-fit statistics during calibration were NSE $>0.9$, RMSE within two standard deviations of the mean measured value, and relative error less than $30 \%$.

\section{ASSESSING IrRigation MANAGEMENT STRATEgIES}

After validating DSSAT-CSM v4.6 for simulating corn growth and development using CERES-Maize, the model was used to assess three deficit irrigation management strategies: (1) the effect of initiating irrigation scheduling at six plant-available water thresholds on yield, water productivity, and net returns with the goal of identifying the threshold that optimizes net returns; (2) the effect of four levels of soil water depletion at planting on grain yield and net returns; and (3) the effect of four planned late season irrigation terminations (based on days after planting) on yield and net returns. A long-term historical weather data set from 1950 to 2013 observed onsite at Kansas State University SWREC near Garden City was used to represent climate variability in southwest Kansas. The seasonal analysis technique described by Tsuji et al. (1994), which involves testing the same management strategies over different weather years to determine the variability in crop performance associated with the interactions between weather and management practices, was used in this study. Seasonal analysis does not simulate carryover effects, which are instead simulated in DSSAT-CSM using a different technique called sequential or crop rotation analysis (Thornton et al., 1994). The weather data included maximum and minimum air temperature, precipitation, and solar radiation. Temperature and precipitation were available from 1950 to 2013, but solar radiation was only available from 2000 to 2013. Solar radiation data were extended backward using the Weatherman utility in DSSAT-CSM v4.6 using the procedure described by Soltan and Hoogenboom (2003). The weather generators in DSSAT-CSM (WGEN and SIMMETEO) used 13 years of measured solar radiation to parametrize normal distributions from which solar radiation was sampled separately for wet and dry years. All irrigation management strategies assessed in this study used nitrogen application rates of $22 \mathrm{~kg} \mathrm{ha}^{-1}$ at planting and $242 \mathrm{~kg} \mathrm{ha}^{-1}$ as side dress. All irrigation was by sprinkler with application efficiency of 0.95; the application efficiency assumed is for low-elevation spray application (LESA), which is commonly used in the Central Plains by farmers with low-capacity wells. All assessed deficit irrigation strategies used a uniform plant population of 7.7 plants $\mathrm{m}^{-2}$ and row spacing of $76 \mathrm{~cm}$.

In addition to the uncertainty in yields associated with variable climate, the sensitivity of management strategies to corn prices was also considered. Variability in weather data from 1950 to 2013 was assumed to represent future weather uncertainty in southwest Kansas. By computing yields for each management strategy, a distribution of yields for each strategy was produced, allowing conversion of uncertainty in weather into uncertainty in yields. The risk to net returns associated with each management strategy was estimated by evaluating the sensitivity of the management strategy to a range of possible corn prices in southwest Kansas. Corn prices considered in this analysis were $\$ 0.10, \$ 0.14, \$ 0.18$, and $\$ 0.26 \mathrm{~kg}^{-1}$, representing the range of corn prices over the last four years, which included drought years (2011 and 2012) and high rainfall years (2010). Cost estimates for irrigation $\left(\$ 0.029 \mathrm{~m}^{-3}\right)$, seed, nitrogen fertilizer, herbicides, phosphorus, potassium, crop consulting, and insurance for a target yield of at least $13.2 \mathrm{Mg} \mathrm{ha}^{-1}$ were obtained from Dhuyvetter et al. (2014). Other base production costs related to land charges and machinery expenses were also included, as provided by Dhuyvetter et al. (2014) for southwest Kansas. Net returns were estimated using equation 4 :

$$
\begin{aligned}
\text { Net return } & =\text { Price }_{k} \times \text { Yield }_{k} \\
& -\sum\left(\text { Cost }_{j, k} \times \text { Input }_{j, k}\right) \\
& - \text { Base production costs }
\end{aligned}
$$

where $k$ is a given year, $j$ is input in a given year $k$.

\section{Criteria for Determination of Efficient \\ Deficit Irrigation Strategies}

The most efficient irrigation management strategy was determined using the mean-Gini dominance (MGD) analysis technique (Tsuji et al., 1998). The MGD decision criteria state that if two risky management strategies $A$ and $B$ have the following characteristics, as shown in equation 5 , then $A$ is the more efficient of the two strategies:

$$
\begin{aligned}
E(A) & \geq E(B) \\
\text { and } E(A)-G(A) & \geq E(B)-G(B)
\end{aligned}
$$

where $E($.$) is the expected value and G($.$) is the Gini-mean$ difference of distributions $A$ and $B$.

The MGD decision criteria approach assumes that the decision maker is averse to risk and helps to avoid risky strategies. The Gini-mean difference in equation 5 is a function of the Gini coefficient, a measure of statistical dispersion. The Gini coefficient is computed as half of the Gini-mean difference expressed as in equation 6 for unordered data following Dixon et al. (1987): 


$$
G=\frac{\sum_{i=1}^{n} \sum_{j=1}^{n}\left|x_{i}-x_{j}\right|}{2 n^{2} \mu}
$$

where $\left|x_{i}-x_{j}\right|$ is the absolute difference of a randomly selected pair of values of a random variable, and $\mu$ is the arithmetic mean.

\section{Deficit Irrigation Simulation}

For all management strategies, irrigation amounts were limited to $25 \mathrm{~mm}$ per event. Planting occurred on 4 May of each year. Using the seasonal analysis technique, we tested the effect of initiating irrigation at $80 \%, 70 \%, 60 \%, 50 \%$, $40 \%$, and $30 \%$ plant-available water on yield, seasonal evapotranspiration, water productivity, and net returns. The model was set up to automatically irrigate when soil water in the top $1.2 \mathrm{~m}$ fell below the set threshold. Current extension bulletins (Rogers, 2007) recommend initiating irrigation when plant-available water drops to $50 \%$, since below this threshold the crop is anticipated to experience water stress. As well capacities diminish, there is increasing interest in deficit irrigation strategies that might not necessarily maximize yields but would maximize net returns.

The effect of four soil water depletion levels at planting $(0 \%, 25 \%, 50 \%$, and $75 \%$ depletion) when irrigation capacities are limited to meet high water demands during critical periods was assessed. For all soil water depletion levels, $25 \mathrm{~mm}$ of irrigation was applied every five days. A total of 16 irrigation applications were made under this strategy. In southwest Kansas, irrigation is typically initiated during the first week of June but could vary depending on seasonal rainfall. The effect of each strategy on grain yield, seasonal transpiration, end of season extractable soil water at maturity and economic net returns was assessed.

The effect of planned late irrigation season termination to encourage soil water mining toward the end of the growing season was assessed. Four management strategies were assessed, including terminating irrigation at 105 days after planting (DAP), at 100 DAP, at 95 DAP, and at 90 DAP. The effect of these four strategies on yield, extractable soil water at maturity, water productivity, seasonal transpiration, and net returns was quantified. Irrigations were not based on soil moisture status but instead used a constant frequency, since irrigation capacity was assumed limited. Recent work by Lamm et al. (2012) indicated that regional producers on average leave residual soil water at harvest of $60 \%$ plant-available water in a $2.4 \mathrm{~m}$ soil profile. However, they reported great variability between producer fields, indicating a need for producers to monitor soil water in their fields. Due to diminished well capacities, many producers believe their wells cannot cope with high corn water needs and continuously irrigate throughout the season.

\section{RESULTS AND DISCUSSIONS}

\section{Model Calibration AND VAlidation}

Figure 1 shows a graphical comparison between measured and simulated yields in 2010, and statistical performance measures are shown in tables 4 and 5 . The calibrated

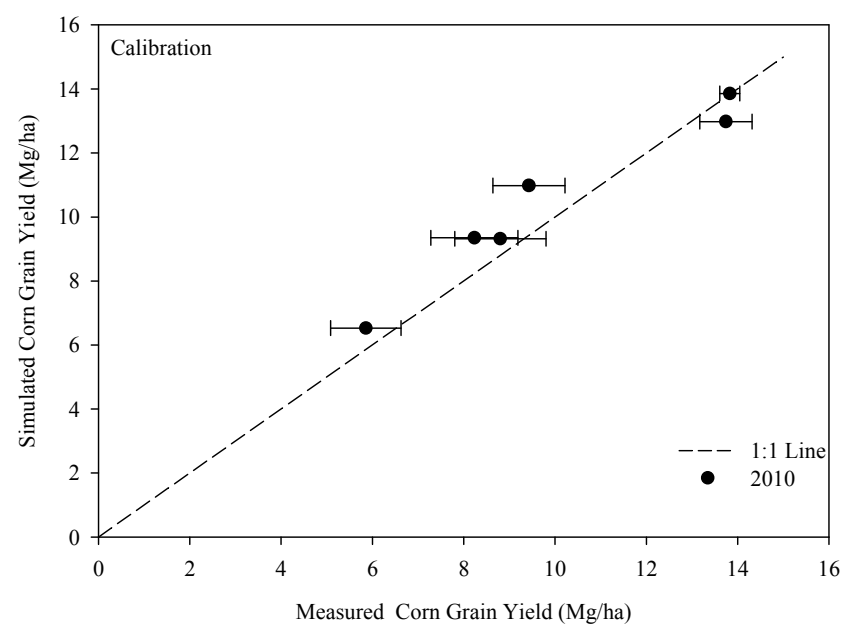

Figure 1. Measured and simulated yield for the calibrated CERESMaize model using 2010 corn growing season data at SWREC near Garden City, Kansas.

model performed very well under full irrigation, with the simulated yield within one standard deviation of the measured yield. The model also performed adequately under deficit irrigation, with simulated yields approximately two standard deviations from measured yields. The calibrated model was validated using all six irrigation treatments for the 2011 and 2012 growing seasons.

Figure 2 shows validation results for grain yield for the 2011 and 2012 corn growing seasons. The NSE for both years was greater than 0.95 , indicating that the model was able to adequately predict grain yield. The RMSE, ex-

Table 4. Goodness-of-fit indicators for validation of the CERESMaize model in DSSAT-CSM v4.6 for simulating corn growth, development and yield at SWREC near Garden City, Kansas.

\begin{tabular}{|c|c|c|c|c|c|c|}
\hline \multirow[b]{2}{*}{ Variable $^{[a]}$} & \multicolumn{3}{|c|}{$\mathrm{NSE}^{[\mathrm{b}]}$} & \multicolumn{3}{|c|}{$\% \mathrm{RMSE}^{[\mathrm{c}]}$} \\
\hline & $2010^{[\mathrm{d}]}$ & $2011^{[\mathrm{e}]}$ & $2012^{[\mathrm{e}]}$ & 2010 & 2011 & 2012 \\
\hline$\overline{\text { Yield }\left(\mathrm{Mg} \mathrm{ha}^{-1}\right)}$ & 0.96 & 0.97 & 0.98 & 9 & 19 & 13 \\
\hline Dry matter $\left(\mathrm{Mg} \mathrm{ha}^{-1}\right)$ & 0.95 & 0.98 & 0.99 & 20 & 17 & 10 \\
\hline $\begin{array}{l}\text { Water productivity } \\
\qquad\left(\mathrm{kg} \mathrm{ha}^{-1} \mathrm{~mm}^{-1}\right)\end{array}$ & 0.98 & 0.96 & 0.97 & 10 & 22 & 16 \\
\hline $\begin{array}{l}\text { Irrigation WUE } \\
\qquad\left(\mathrm{kg} \mathrm{ha}^{-1} \mathrm{~mm}^{-1}\right)\end{array}$ & 0.94 & 0.94 & 0.90 & 25 & 24 & 27 \\
\hline Harvest index & 0.93 & 0.86 & 0.98 & 22 & 39 & 14 \\
\hline Maximum LAI & 0.88 & 0.87 & 0.77 & 23 & 27 & 35 \\
\hline
\end{tabular}

[a] $\mathrm{WUE}=$ water use efficiency, and LAI = leaf area index.

[b] Nash-Sutcliff coefficient of efficiency.

[c] RMSE expressed as a percentage of mean measured value.

[d] Calibration year.

[e] Validation year.

Table 5. Relative error between measured and simulated yield and aboveground dry matter at SWREC near Garden City, Kansas, from 2010 to 2012.

\begin{tabular}{ccccccccc}
\hline & \multicolumn{3}{c}{$\begin{array}{c}\text { Yield Relative Error } \\
\left(\mathrm{Mg} \mathrm{ha}^{-1}\right)\end{array}$} & & \multicolumn{3}{c}{$\begin{array}{c}\text { Aboveground Dry Matter } \\
\text { Relative Error } \\
\left(\mathrm{Mg} \mathrm{ha}^{-1}\right)\end{array}$} \\
\cline { 2 - 4 } \cline { 6 - 8 } Treatment & $2010^{[\mathrm{a}]}$ & $2011^{[\mathrm{b}]}$ & $2012^{[\mathrm{b}]}$ & & 2010 & 2011 & 2012 \\
\hline 1 & 0.00 & 0.12 & 0.06 & & 0.22 & 0.06 & 0.01 \\
2 & 0.06 & 0.17 & 0.17 & & 0.14 & 0.00 & 0.10 \\
3 & 0.14 & 0.05 & 0.01 & & 0.20 & 0.48 & 0.07 \\
4 & 0.12 & 0.30 & 0.08 & & 0.12 & 0.11 & 0.16 \\
5 & 0.06 & 0.02 & 0.29 & & 0.31 & 0.03 & 0.16 \\
6 & 0.10 & ${ }_{-[\mathrm{c}]}$ & 0.74 & & 0.14 & 0.38 & 0.35 \\
\hline
\end{tabular}

[a] Calibration year.

[b] Validation year.

[c] Zero yield was measured in 2011 for treatment 6 . 


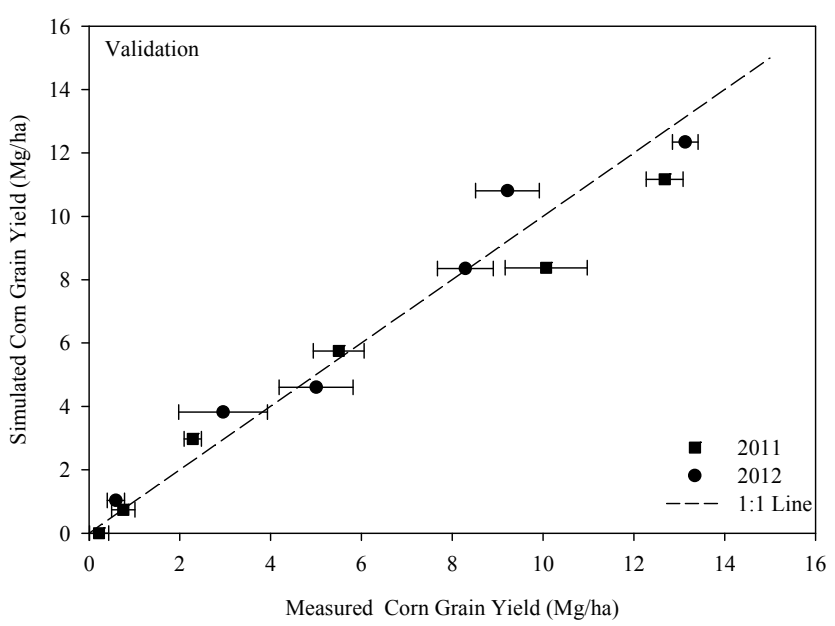

Figure 2. Simulated and measured corn grain yields for full and deficit irrigated corn for 2011 and 2012 growing seasons at SWREC near Garden City, Kansas.

pressed as a percentage of the mean measured value for both years, ranged between 0.13 and 0.19 , as shown in table 4 . The difference between simulated and measured grain yield was 1.5 and $0.79 \mathrm{Mg} \mathrm{ha}^{-1}$ for treatment 1 in 2011 and 2012, respectively. These differences were within two standard deviations of the average measured yield. Standard deviations for measured grain yield in treatment 1 were 0.81 and $0.57 \mathrm{Mg} \mathrm{ha}^{-1}$ for the 2011 and 2012 growing seasons, respectively. As previously reported by others (Saseendran et al., 2008; Todorovic et al., 2009; DeJonge et al., 2011), DSSAT-CSM CERES-Maize tends to predict yields for fully irrigated treatments better than for deficit irrigated treatments. However, DeJonge et al. (2012) showed that performance of the model under water stress can be improved by calibrating the model using data from a wide range of deficit irrigation levels, which is the approach used in this study.

The observed difference between simulated and measured corn grain yields shown by the deviation from the 1:1 line in figure 2 could be attributed to model prediction uncertainty due to the model's inability to include all possible biophysical processes taking place in the field (e.g., weed water use due to reduced canopy, pests and diseases, etc.) as well as uncertainty in the measured data (shown by the standard error bars in fig. 2). Yields for treatments 3 to 6 were also adequately predicted, as shown in figure 2 and by the statistical performance measures in tables 4 and 5 with NSE $>0.9$ and RMSE relative to average measured yield ranging from 0.13 to 0.19 .

Aboveground biomass for 2011 and 2012 had NSE greater than 0.9 and RMSE relative to average measured aboveground biomass of 0.1 to 0.17 , as shown in tables 4 and 5 and figure 3 , with the amount of biomass decreasing with applied irrigation, as expected. Based on goodness-offit statistics for both years, the model's ability to predict aboveground dry matter was acceptable. Relative error of aboveground biomass was higher than that of grain yield, particularly for 2010. This difference could be attributed to several factors, including overprediction of aboveground biomass by the model during the wet year of 2010 and un-

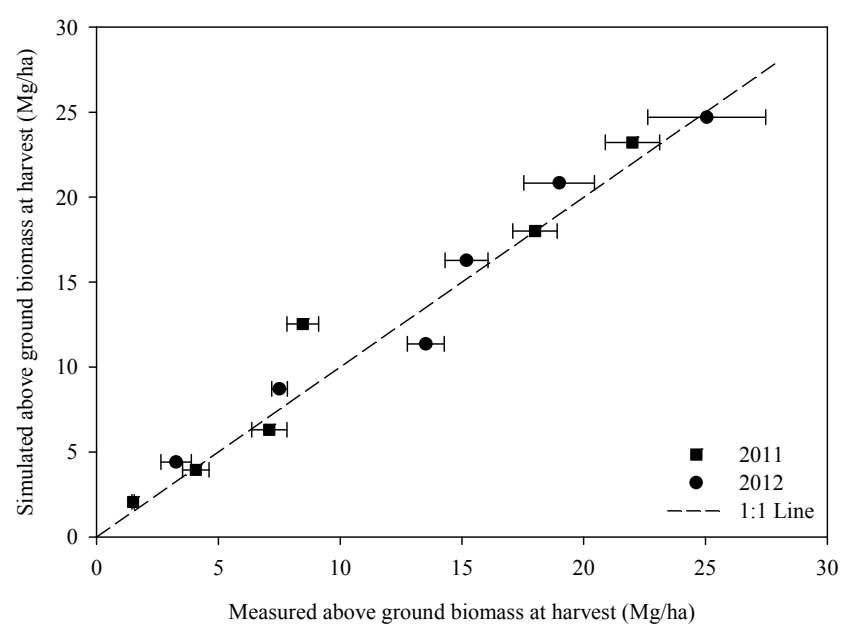

Figure 3. Simulated and measured aboveground dry matter for full and deficit irrigated corn for 2011 and 2012 growing seasons at SWREC near Garden City, Kansas.

certainty in measurements during the drought years of 2011 and 2012. It worth noting that one of DSSAT's weaknesses under water stress conditions is its inability to relate soil water stress factors to phenological development. The water stress factors are only related to biomass accumulation, which could result in overprediction of aboveground biomass under water stress since the effects of water stress on phenological development are not well represented. Leaf area index was overpredicted at high water levels and slightly underpredicted at low water levels, with NSE values of 0.88 and 0.77 and \%RMSE of values of 0.27 and 0.35 for 2011 and 2012, respectively. Overall, based on all the performance statistics (tables 4 and 5), the model's ability to predict corn growth, grain yield, and water use under full and deficit irrigation was acceptable, and therefore we developed confidence in applying the model for assessing different deficit irrigation management strategies for corn under southwest Kansas climatic conditions and soils.

\section{OPTIMUM SOIL WATER THRESHOLD FOR INITIATING IRRIGATION}

The calibrated and validated model was applied to determine the optimum plant-available water (PAW) threshold for maximizing net returns with limited water. Averaged over 63 years of historical weather data, mean grain yield for the different irrigation scheduling triggers are shown in table 6 . There was no appreciable difference $\left(<0.02 \mathrm{Mg} \mathrm{ha}^{-1}\right)$ in mean yield for irrigation schedules based on $80 \%, 70 \%, 60 \%$, and $50 \%$ PAW. Mean yield slightly decreased at $40 \%$ and $30 \%$ PAW. Mean yield differences between triggering irrigation at 50\% PAW and at $40 \%$ and $30 \%$ PAW were 0.07 and $0.72 \mathrm{Mg} \mathrm{ha}^{-1}$, respectively. The results in table 6 support current extension bulletin recommendations (Rogers, 2007) for scheduling irrigation based on a $50 \%$ PAW threshold since only a small increase in yield is gained by scheduling irrigation based on greater thresholds. Using crop yield response data from several locations from North Dakota to Kansas, Hereen et al. (2011) showed that moderate deficit irrigation resulted in negligible impact on corn yield and that an available soil 
Table 6. Mean corn yields for different plant-available water (PAW) thresholds averaged over 63 years (1950 to 2013) of weather data at SWREC near Garden City, Kansas.

\begin{tabular}{cccc}
\hline Treatment & Description & $\begin{array}{c}\text { Mean } \\
\left(\mathrm{Mg} \mathrm{ha}^{-1}\right)\end{array}$ & $\begin{array}{c}\mathrm{SD} \\
\left(\mathrm{Mg} \mathrm{ha}^{-1}\right)\end{array}$ \\
\hline 1 & $80 \%$ PAW & 13.65 & 1.68 \\
2 & $70 \%$ PAW & 13.65 & 1.68 \\
3 & $60 \%$ PAW & 13.64 & 1.68 \\
4 & $50 \%$ PAW & 13.63 & 1.68 \\
5 & $40 \%$ PAW & 13.56 & 1.70 \\
6 & $30 \%$ PAW & 12.91 & 1.89 \\
\hline
\end{tabular}

water threshold of $50 \%$ during the mid-season was sufficient. Based on experimental data from subsurface drip irrigated corn studies in northwest Kansas, Lamm and Aboukheira (2009) indicated that maximizing yields required maintaining plant-available water in deep silt loam soils at $70 \%$, highlighting the need to take into account sitespecific management and yield goals in deciding the optimum plant-available water thresholds.

If the production goal is to maximize net returns under limited water supplies, scheduling irrigation based on a $40 \%$ or $50 \%$ PAW trigger was the optimum choice at a corn price of $\$ 0.10 \mathrm{~kg}^{-1}$. When the corn price was raised to $\$ 0.14 \mathrm{~kg}^{-1}$, triggering irrigation based on a PAW of $50 \%$ maximized net returns. When the corn price was further increased to $\$ 0.18$ and $\$ 0.26 \mathrm{~kg}^{-1}$, triggering irrigation based on a PAW of 50\% maximized net returns, as shown in table 7. The MGD risk analysis criteria used in table 7 are based on the premise that the management strategy that has the highest $E(x)$ and $E(x)-G(x)$ (from eq. 5) is most efficient or presents the least risk of lowering net returns. From the cumulative probability density functions for net returns shown in figure 4 , it can be seen that a PAW trigger of $50 \%$ appears dominant at different corn prices even though its difference with higher triggers narrows as corn prices increase, indicating that the best long-term strategy for scheduling irrigation based on soil water is $50 \%$ PAW.

Figure 5 illustrates uncertainty in various simulated production variables for the different irrigation scheduling treatments. The only source of uncertainty is annual variations in weather. Mainly due to precipitation, annual yields for each trigger varied, as represented by the 25th, 50th, 75 th, and 100th percentiles on the boxplots. The uncertainty in the number of irrigation applications required to manage soil water at a given threshold shows that managing irrigation scheduling at greater PAW thresholds resulted in more irrigation applications and more seasonal evapotranspiration without substantial changes in yield, implying that the extra water might have been lost to deep percolation, soil evaporation, or recharge of the soil profile rather than transpiration. The amount of corn grain produced per unit of evapotranspiration was maximized at $50 \%$ PAW thresholds. This simulation analysis suggests that operating at higher thresholds not only resulted in more water use but also lower crop water productivity, as shown in the lower right panel of figure 5. Operating at very low PAW similarly reduced net returns.

The 50th percentile number of irrigations required for the $80 \%, 70 \%, 60 \%, 50 \%, 40 \%$, and $30 \%$ PAW irrigation scheduling thresholds was less than $17,15,14,13,12$, and 10 , respectively. The 75 th percentile number of irrigation applications required for managing irrigation at $50 \%$ PAW was 14 or less, while the other higher PAW thresholds required 5, 2, and 1 more irrigation events compared to the $50 \%$ threshold. In order to allow for interannual variations in rainfall or irrigation system downtime for repairs, it may be advisable to plan based on a 75th to 100th percentile, resulting in seasonal irrigation needs of between 14 to 17 applications (355 to $431 \mathrm{~mm}$ ). Based on the results from this analysis, it appears that triggering irrigation based on a PAW of $50 \%$ will maximize net returns in most years at various corn prices.

\section{EfFect of SoIl Water at Planting on Yield}

Mean yields and net returns for starting with $0 \%, 25 \%$, $50 \%$, and $75 \%$ soil water depletion in the top $1.2 \mathrm{~m}$ of the root zone at planting are summarized in tables 8 and 9 . This analysis indicates that starting with $0 \%$ soil water depletion in the top $1.2 \mathrm{~m}$ at planting maximized net returns. All strategies in table 8 received the same amount of irrigation ( $25 \mathrm{~mm}$ every five days starting 35 days after planting up to 110 days after planting). It is worth noting that an irrigation frequency of one $25 \mathrm{~mm}$ application every five days could be considered deficit irrigation for the climatic conditions of southwest Kansas since mean daily irrigation requirement can exceed $7 \mathrm{~mm} \mathrm{~d}^{-1}$. Yields for starting with $0 \%$ and $25 \%$ soil water depletion at planting were not substantially different (table 8). There was a reduction in yield of $0.18 \mathrm{Mg} \mathrm{ha} \mathrm{h}^{-1}$ when soil water was depleted by $50 \%$ at planting. If soil water was depleted by $75 \%$ at planting, reductions in yield were approximately $4.3 \%$. Planting when soil water was depleted by $50 \%$ and $75 \%$ resulted in reductions in net returns that increased with an increase in corn price, as shown in table 9. This implies that producers with low-capacity systems could maximize their net returns if soil water in the top $1.2 \mathrm{~m}$ of the soil profile is in the range of $0 \%$ to $25 \%$ soil water depletion at planting. Starting with sufficient soil water at planting can buffer the crop against short-term water stress between irrigation or rainfall

Table 7. Net returns for different plant-available water (PAW) irrigation scheduling thresholds and corn prices averaged over 63 years $(1950$ to 2013) of weather data at SWREC near Garden City, Kansas. ${ }^{[a]}$

\begin{tabular}{|c|c|c|c|c|c|c|c|c|}
\hline \multirow[b]{2}{*}{ Treatment } & \multicolumn{2}{|c|}{$\$ 0.10 \mathrm{~kg}^{-1}$} & \multicolumn{2}{|c|}{$\$ 0.14 \mathrm{~kg}^{-1}$} & \multicolumn{2}{|c|}{$\$ 0.18 \mathrm{~kg}^{-1}$} & \multicolumn{2}{|c|}{$\$ 0.26 \mathrm{~kg}^{-1}$} \\
\hline & $E(x)$ & $E(x)-G(x)$ & $E(x)$ & $E(x)-G(x)$ & $E(x)$ & $E(x)-G(x)$ & $E(x)$ & $E(x)-G(x)$ \\
\hline $80 \%$ PAW & 270 & 187 & 745 & 628 & 1207 & 1059 & 2145 & 1931 \\
\hline $70 \%$ PAW & 291 & 208 & 765 & 649 & 1228 & 1080 & 2165 & 1952 \\
\hline $60 \%$ PAW & 299 & 216 & 774 & 658 & 1236 & 1088 & 2174 & 1960 \\
\hline $50 \%$ PAW & 306 & 223 & 780 & 665 & 1243 & 1095 & 2179 & 1966 \\
\hline $40 \%$ PAW & 308 & 225 & 780 & 663 & 1240 & 1090 & 2171 & 1956 \\
\hline $30 \%$ PAW & 263 & 171 & 712 & 584 & 1149 & 986 & 2036 & 1800 \\
\hline
\end{tabular}

$E(x)$ is the expected value $\left(\$ \mathrm{ha}^{-1}\right)$, and $G(x)$ is the Gini-mean difference $\left(\$ \mathrm{ha}^{-1}\right)$. The management strategy that has the highest $E(x)$ and $E(x)$ - $G(x)$ is the most efficient or presents least the risk to net returns. 

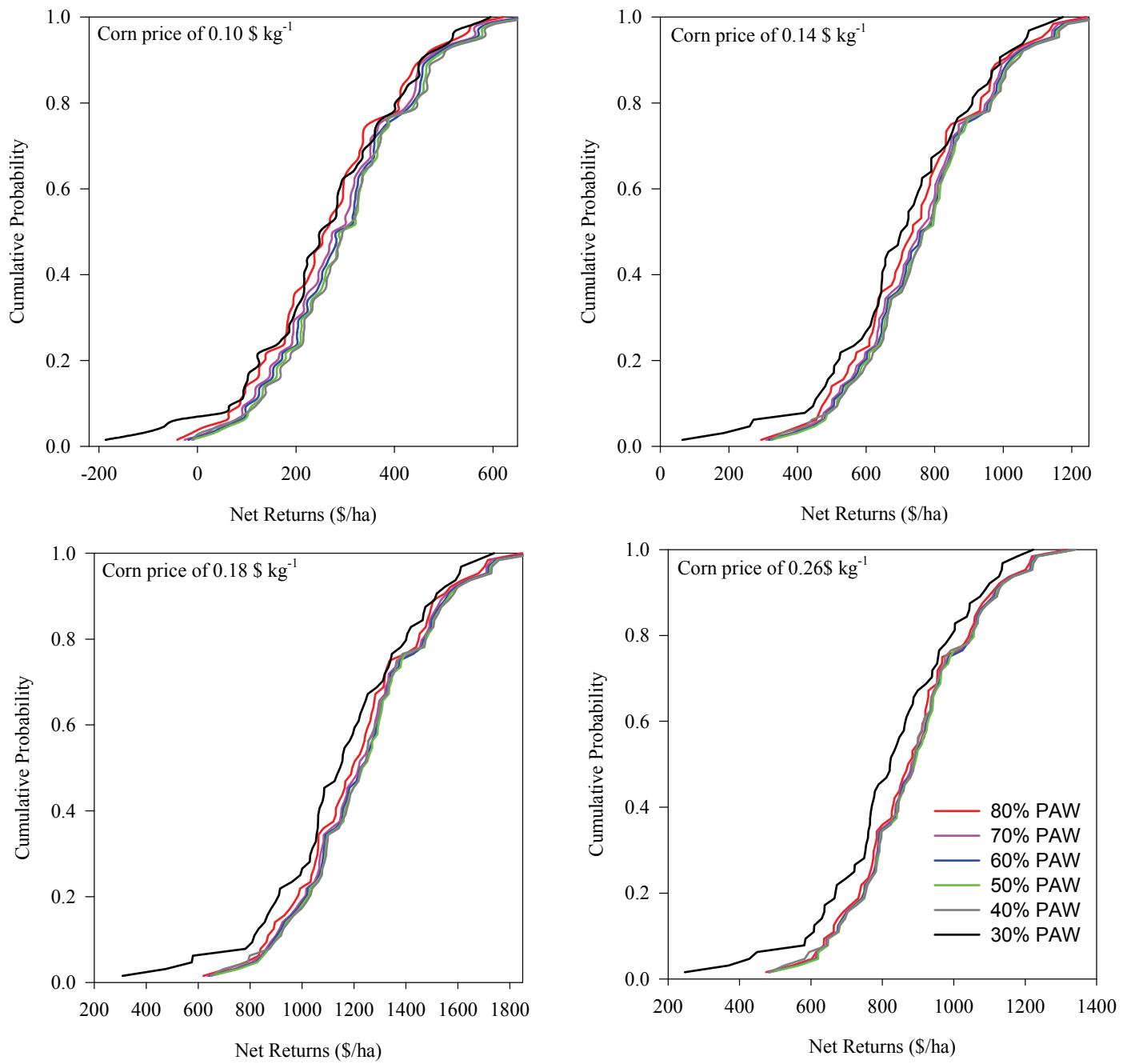

Figure 4. Probability or risk to net returns associated with triggering irrigation scheduling at different levels of plant-available water at SWREC near Garden City, Kansas.

events. In southwest Kansas, irrigation typically starts in the first part of June depending seasonal rainfall patterns. Small irrigation application amounts immediately after planting are usually not recommended to avoid shallow rooting systems (Lamm et al., 1996). Soil water depletions of $0 \%$ and $25 \%$ at planting consistently maximized net returns based on the MGD decision criteria, i.e., the highest expected value $(E)$ and highest difference between the expected value and Gini-mean difference. In addition, the cumulative probability density function (CDF) curves of $0 \%$ and $25 \%$ soil water depletions at planting were to the right of all other CDF curves, as shown in figure 6 , indicating that they minimized risk of lowering net returns.

Results from this analysis are consist with the recommendation of Stone and Schlegel (2006), who indicated that sufficient soil water at planting improved water productivity. Figure 7 illustrates the uncertainty in grain yield, seasonal transpiration, water productivity, and extractable soil water at maturity associated with each management strategy due to interannual variation in climate. Planting when soil water depletion was in the range of $0 \%$ to $50 \%$ also produced greater seasonal transpiration compared to $75 \%$ soil water depletion (fig. 7). Water productiv- ity was not substantially different among the different starting soil water depletions. However, the amount of extractable soil water at physiological maturity increased with reduction in soil water depletion at planting (fig. 7).

There are different ways of ensuring sufficient soil water at planting, e.g., through late spring preseason irrigation, from increasing soil water storage of winter precipitation, or through fallowing and residue management. Lamm et al. (2012) noted that preseason irrigation might not be warranted for corn production in the Great Plains since in many producers' fields soil water at harvest averaged $60 \%$ of plant-available water and maintaining soil water at this level at harvest would maximize winter precipitation storage. Schlegel et al. (2011) indicated that preseason irrigation might be beneficial for low-capacity systems for increasing crop productivity. If the cost of bringing soil water content to a desired level at planting by preseason irrigation or fallowing is known, it needs to be included as a cost in the economic analysis. Although not commonly used in irrigated cropping systems, fallowing combined with weed control could increase soil water at planting. An optimum strategy to achieve desired levels of soil water at planting could involve mining already stored soil water toward the 


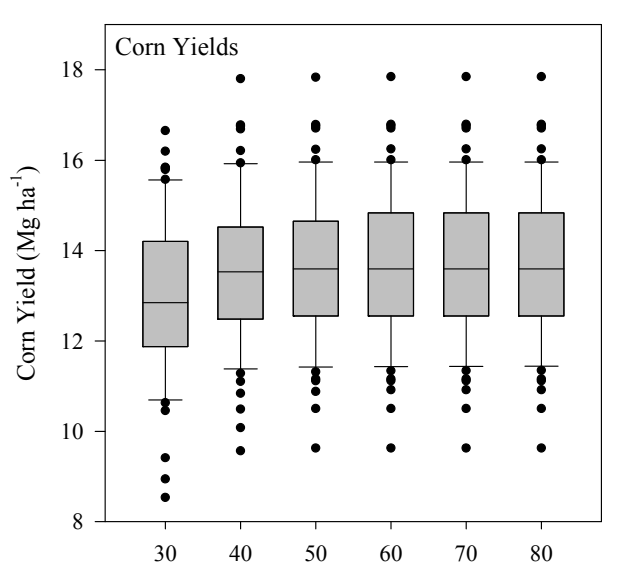

$\%$ of Plant Available Water as Irrigation Scheduling Trigger

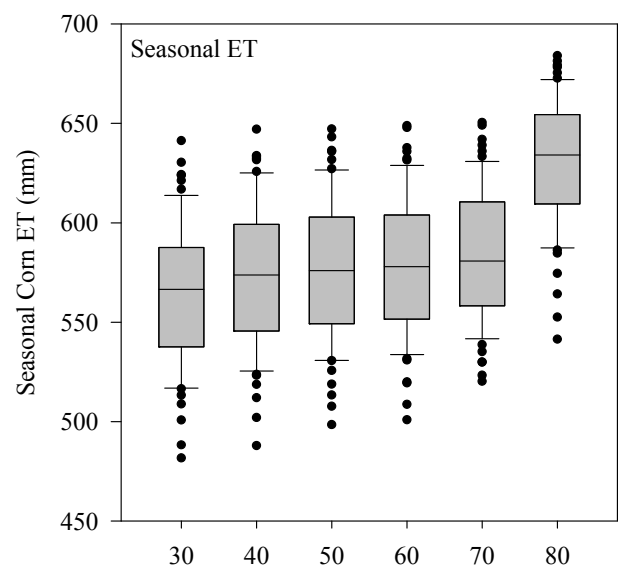

$\%$ of Plant Available Water as Irrigation Scheduling Trigger

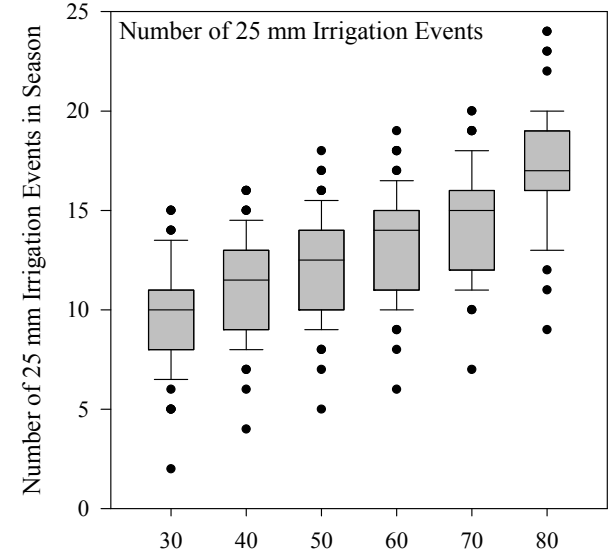

$\%$ of Plant Available Water as Irrigation Scheduling Trigger

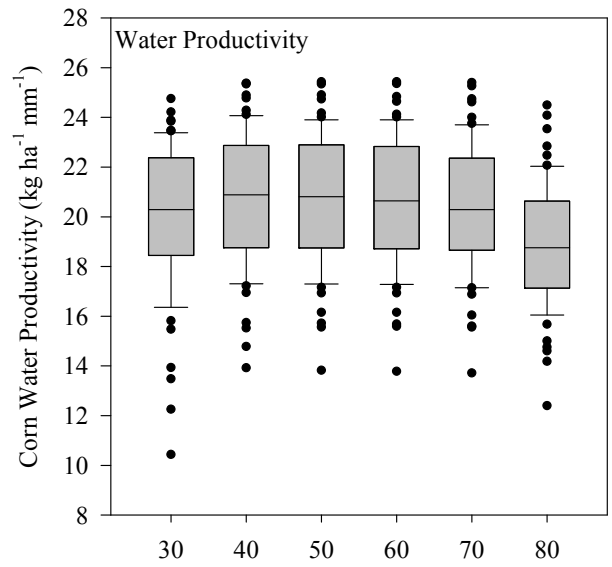

$\%$ of Plant Available Water as Irrigation Scheduling Trigger

Figure 5. Uncertainty in simulated corn yields, number of irrigations events required, water productivity, and seasonal evapotranspiration associated with triggering irrigation at different levels of plant-available water at SWREC near Garden City, Kansas. Black dots represent outliers or values greater than 1.5 interquartile ranges away from the 25 th or 75 th percentiles.

Table 8. Mean corn yields for different percentages soil water depletion at planting (SWP) in the top $1.2 \mathrm{~m}$ averaged over 63 years (1950 to 2013) of weather data at SWREC near Garden City, Kansas.

\begin{tabular}{cccc}
\hline Treatment & Description & $\begin{array}{c}\text { Mean } \\
\left(\mathrm{Mg} \mathrm{ha}^{-1}\right)\end{array}$ & $\begin{array}{c}\text { SD } \\
\left(\mathrm{Mg} \mathrm{ha}^{-1}\right)\end{array}$ \\
\hline 1 & $0 \%$ SWP & 13.64 & 1.5 \\
2 & $25 \%$ SWP & 13.63 & 1.5 \\
3 & $50 \%$ SWP & 13.39 & 1.6 \\
4 & $75 \%$ SWP & 12.88 & 1.9 \\
\hline
\end{tabular}

end of the season by targeting available soil water of $50 \%$ at harvest in order to create space for winter precipitation storage, followed by controlled spring preseason irrigation before planting to bring soil water to between $0 \%$ to $25 \%$ depleted at planting.

\section{EFFECT OF LATE SEASON IRRIGATION TERMINATION ON YiELd AND WATER PRODUCTIVITY}

Mean yields and net returns from terminating irrigation at different days after planting are shown in tables 10 and 11. Initial soil water at planting was $0 \%$ depleted, and irrigation frequency was every five days starting 35 days after planting. Terminating irrigation at 105, 100, and 95 days after planting produced the highest yields, but terminating irrigation at 90 days after planting maximized net returns at a corn price of $\$ 0.10 \mathrm{~kg}^{-1}$. Terminating irrigation at 95 or 90 days after planting maximized net returns for a corn price of $\$ 0.14 \mathrm{~kg}^{-1}$, as shown in table 11 . Terminating irrigation at 95 days after planting maximized net returns for corn prices of $\$ 0.18$ and $\$ 0.26 \mathrm{~kg}^{-1}$. Figure 8 indicates that the strategy of terminating irrigation at 95 or 90 days after planting was consistently to the right of all other cumula-

Table 9. Net returns for different percentages soil water depletion at planting (SWP) in the top $1.2 \mathrm{~m}$ averaged over $63 \mathrm{years}(1950$ to 2013$)$ of weather data at SWREC near Garden City, Kansas. ${ }^{[a]}$

\begin{tabular}{|c|c|c|c|c|c|c|c|c|}
\hline \multirow[b]{2}{*}{ Treatment } & \multicolumn{2}{|c|}{$\$ 0.10 \mathrm{~kg}^{-1}$} & \multicolumn{2}{|c|}{$\$ 0.14 \mathrm{~kg}^{-1}$} & \multicolumn{2}{|c|}{$\$ 0.18 \mathrm{~kg}^{-1}$} & \multicolumn{2}{|c|}{$\$ 0.26 \mathrm{~kg}^{-1}$} \\
\hline & $E(x)$ & $E(x)-G(x)$ & $E(x)$ & $E(x)-G(x)$ & $E(x)$ & $E(x)-G(x)$ & $E(x)$ & $E(x)-G(x)$ \\
\hline $0 \%$ SWP & 286 & 213 & 760 & 657.9 & 1223 & 1092 & 2160 & 1970 \\
\hline $25 \%$ SWP & 285 & 212 & 759 & 656.2 & 1221 & 1089 & 2157 & 1967 \\
\hline $50 \%$ SWP & 265 & 189 & 730 & 623.7 & 1184 & 1048 & 2104 & 1906 \\
\hline $75 \%$ SWP & 221 & 130 & 670 & 541.0 & 1106 & 942 & 1991 & 1753 \\
\hline
\end{tabular}

[a] $E(x)$ is the expected value $\left(\$ \mathrm{ha}^{-1}\right)$, and $G(x)$ is the Gini-mean difference $\left(\$ \mathrm{ha}^{-1}\right)$. 

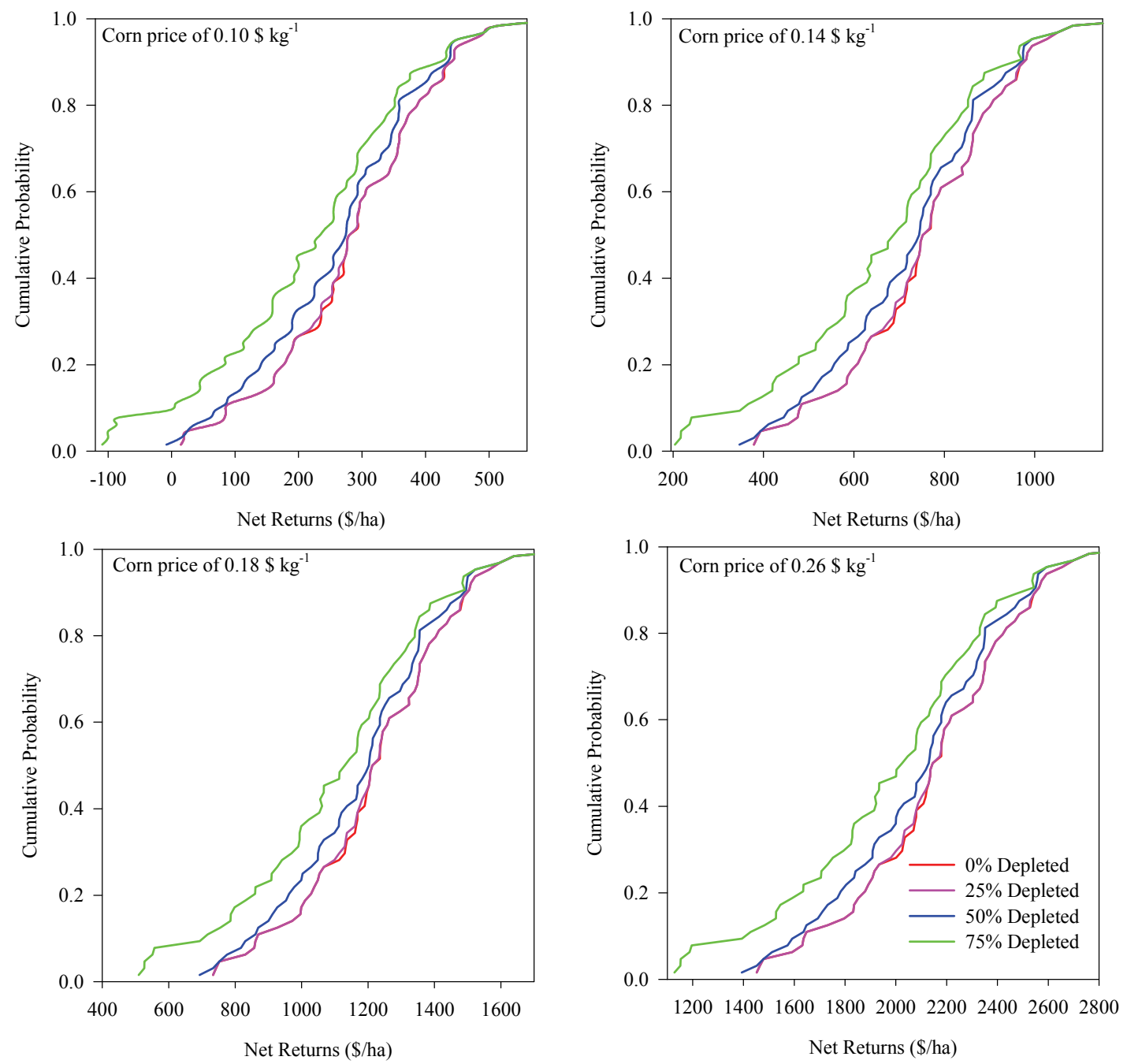

Figure 6. Probability or risk to net returns associated with percentage soil water depletion at planting in the top $1.2 \mathrm{~m}$ at SWREC near Garden City, Kansas.

tive probability curves, although the difference decreased with an increase in corn price, implying that it presented the lowest risk to lowering net returns. Figure 8 also indicates that the difference between irrigation termination strategies is very small, implying that inappropriate end of season irrigation termination could easily move between efficient and non-efficient management based on the MGD criteria, and therefore it should be done carefully. Figure 9 indicates that terminating irrigation at 105 days after planting resulted in the highest extractable soil water at physiological maturity in the soil profile. Terminating irrigation at 90 days after planting resulted in the lowest extractable soil water at physiological maturity, implying that this strategy allowed the plants to mine the stored water toward the end of the season. Water productivity was not substantially different for irrigation terminations of 90, 95, and 105 days after planting, implying that there was equal increase in yield for each unit of ET for these three strategies.

Since corn is a high water response crop, late season irrigation termination needs to be done carefully to avoid significant yield reductions. Lamm et al. (1996) suggested using ET-based scheduling to forecast crop water needs several weeks before physiological maturity and comparing the forecast to planned management-allowable depletion at physiological maturity in order to beneficially use planned late season irrigation termination management strategies. Planned late season soil water depletion might be a useful strategy, but it requires practical and accurate methods of soil water monitoring that a producer can use on a routine basis. In an on-farm survey of soil water after harvest in several counties in western Kansas, Lamm et al. (2012) reported that most fields had average available soil water above $60 \%$ at harvest, implying that there are opportunities to use late irrigation season termination to encourage use of the already stored soil water, which could create more room for winter soil water storage.

\section{Summary AND CONCLUSION}

Producers in the Central Plains need recommendations for deficit irrigation strategies that can maximize net returns in most years with low well capacities. Deficit irrigation strategies for maximizing net returns for corn under limited water were independently assessed through simulation using the CERES-Maize model in DSSAT-CSM v4.6. The calibrated and validated model was able to predict end 

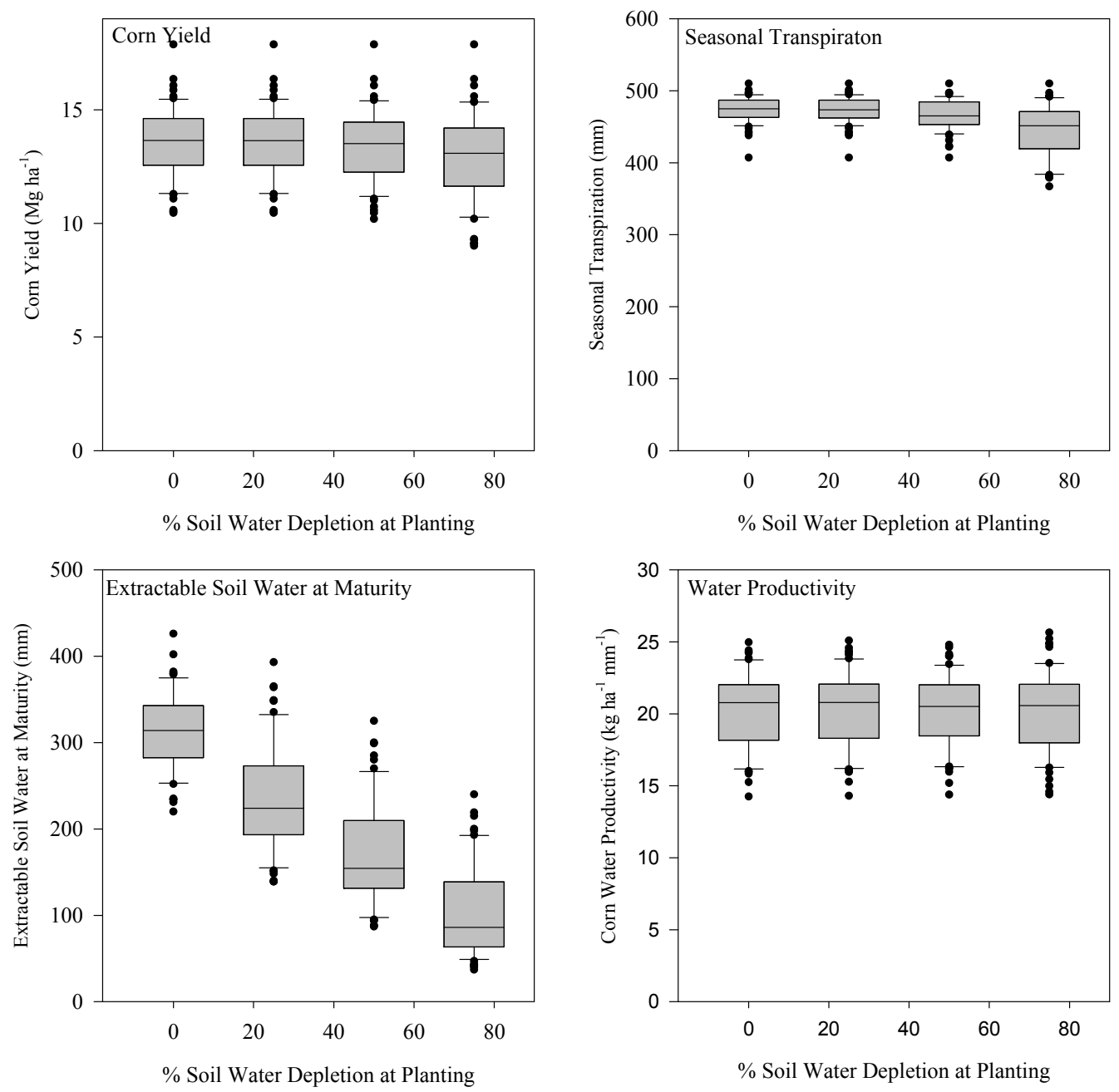

Figure 7. Uncertainty in corn yields, seasonal transpiration, water productivity and extractable soil water at physiological maturity associated with percentage soil water depletion at planting in the top $1.2 \mathrm{~m}$ at SWREC near Garden City, Kansas. Black dots represent outliers or values greater than 1.5 interquartile ranges away from the 25 th or 75 th percentiles.

Table 10. Mean corn yields for different late season irrigation termination strategies expressed in days after planting (DAP) averaged over 63 years (1950 to 2013) of weather data at SWREC near Garden City, Kansas.

\begin{tabular}{cccc}
\hline Treatment & Description & $\begin{array}{c}\text { Mean } \\
\left(\mathrm{Mg} \mathrm{ha}^{-1}\right)\end{array}$ & $\begin{array}{c}\text { SD } \\
\left(\mathrm{Mg} \mathrm{ha}^{-1}\right)\end{array}$ \\
\hline 1 & 105 DAP & 13.64 & 1.5 \\
2 & 100 DAP & 13.64 & 1.5 \\
3 & 95 DAP & 13.63 & 1.5 \\
4 & 90 DAP & 13.59 & 1.5 \\
\hline
\end{tabular}

of season grain yield with acceptable accuracy (NSE $>0.9$, $0.13<\%$ RMSE $<0.19$ ), indicating that the model could be used as a decision support tool for assessing alternative management strategies for optimizing use of limited water for irrigation of corn in southwest Kansas. The analysis indicated that irrigation scheduling based on a $50 \%$ plantavailable water threshold maximized net returns at all corn prices considered ( $\$ 0.10$ to $\$ 0.26 \mathrm{~kg}^{-1}$ ) compared to initiating irrigation at greater soil water content. This recommendation assumes sufficient well capacity to maintain soil water at 50\% PAW throughout the season, which requires matching irrigated land size with available groundwater resources. Accounting for interannual variations in weather and irrigation downtime due to repairs, 14 to 17 irrigation applications of $25 \mathrm{~mm}$ each would be needed to maintain soil water at $50 \%$ of plant-available water during the season.

Planting when soil water depletion in the top $1.2 \mathrm{~m}$ of the soil profile was $0 \%$ maximized net returns at all corn prices considered in this analysis, although the difference with the $25 \%$ soil water depletion strategy was negligible. We recommend whenever possible to have the top $1.2 \mathrm{~m}$ of the soil profile between $0 \%$ and $25 \%$ depleted at planting. This could be accomplished by supplementing winter soil water capture and storage with late spring preseason irrigation for low well capacity systems.

Terminating irrigation at 95 or 90 days after planting maximized net returns at all corn prices considered in this analysis. Terminating irrigation at 90 days after planting also resulted in the lowest extractable soil water at physiological maturity, implying that there are opportunities to mine already stored soil water toward the end of the season, even under deficit irrigation. We recommend that late season irrigation termination be done in conjunction with soil water monitoring and management-allowable depletion techniques to minimize potential reduction in yields that could result from poorly implemented late season irrigation termination. 
Table 11. Net returns for different late season irrigation termination strategies expressed in days after planting (DAP) averaged over 63 years (1950 to 2013) of weather data at SWREC near Garden City, Kansas. ${ }^{[a]}$

\begin{tabular}{|c|c|c|c|c|c|c|c|c|}
\hline \multirow[b]{2}{*}{ Treatment } & \multicolumn{2}{|c|}{$\$ 0.10 \mathrm{~kg}^{-1}$} & \multicolumn{2}{|c|}{$\$ 0.14 \mathrm{~kg}^{-1}$} & \multicolumn{2}{|c|}{$\$ 0.18 \mathrm{~kg}^{-1}$} & \multicolumn{2}{|c|}{$\$ 0.26 \mathrm{~kg}^{-1}$} \\
\hline & $E(x)$ & $E(x)-G(x)$ & $E(x)$ & $E(x)-G(x)$ & $E(x)$ & $E(x)-G(x)$ & $E(x)$ & $E(x)-G(x)$ \\
\hline 105 DAP & 286 & 213 & 760 & 658 & 1223 & 1092 & 2160 & 1970 \\
\hline 100 DAP & 293 & 220 & 767 & 665 & 1230 & 1099 & 2167 & 1977 \\
\hline 95 DAP & 300 & 227 & 774 & 672 & 1236 & 1105 & 2173 & 1983 \\
\hline 90 DAP & 304 & 230 & 777 & 672 & 1238 & 1103 & 2172 & 1977 \\
\hline
\end{tabular}

[a] $E(x)$ is the expected value $\left(\$ \mathrm{ha}^{-1}\right)$, and $G(x)$ is the Gini-mean difference $\left(\$ \mathrm{ha}^{-1}\right)$.
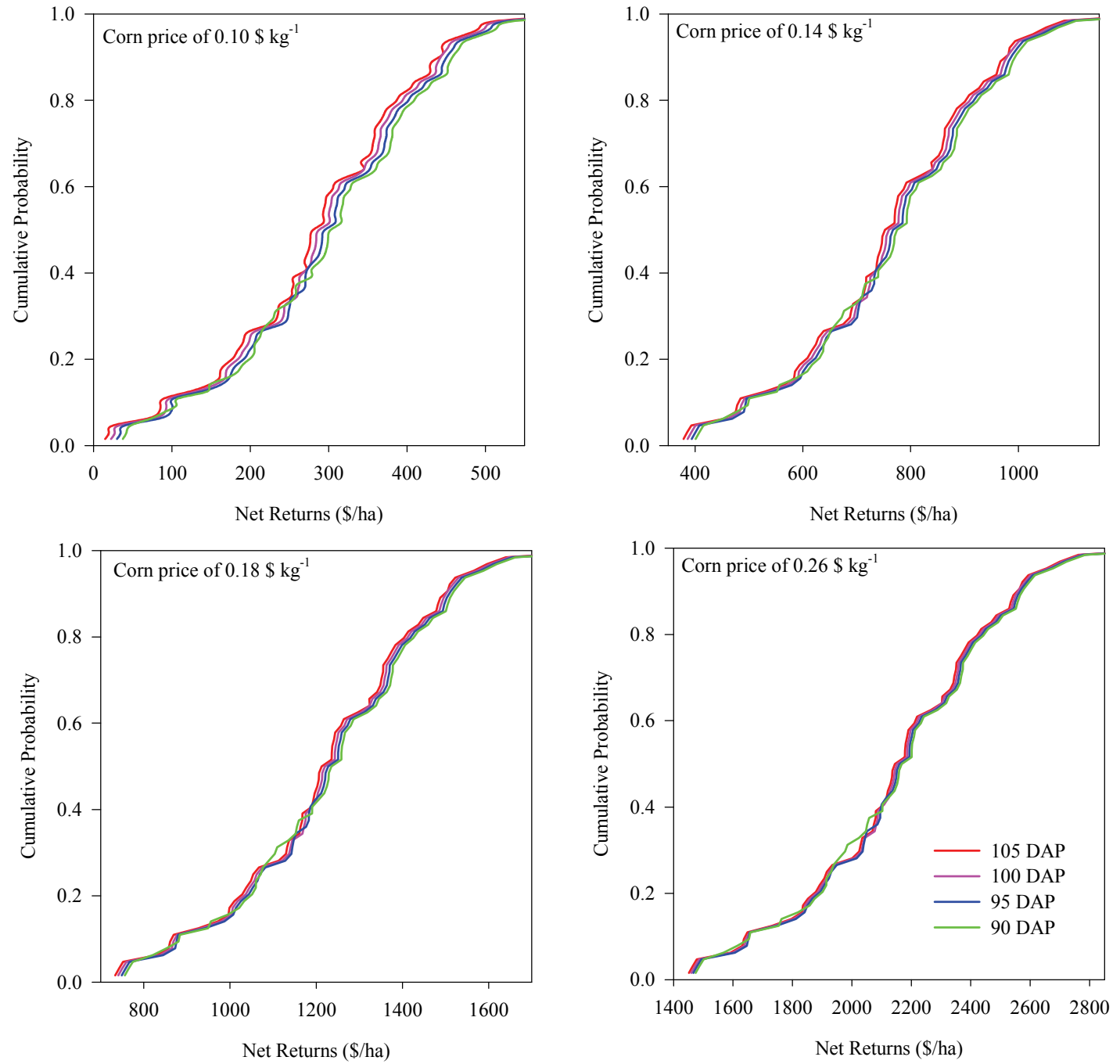

Figure 8. Uncertainty in net returns associated with irrigation season termination expressed in days after planting (DAP) at SWREC near Garden City, Kansas.

It is worth noting that when assessing management strategies through simulation, model predictions are imperfect for several reasons, including model structure simplification of biophysical processes, uncertain model inputs such as errors in weather data, and uncertainty in model parameters. However, despite the imperfections, cropping systems simulation models are useful tools for integrating the interactions of weather, soil, management, and genetic factors. The concepts explored in this analysis involving the application of agricultural systems models to optimize use of limited water resources could be applied in other areas with constrained water supplies for irrigation.

\section{ACKNOWLEDGEMENTS}

The authors would like to thank the Ogallala Aquifer Project for providing funding for the experimental study. The authors would also like to thank Mr. Dennis Tomsicek for data collection and compilation and Mr. Jaylen Koehn for coordinating all agronomic field operations. The authors would also like to thank the anonymous reviewers whose suggestions and comments improved the manuscript. This is contribution no. 15-255-J from the Kansas Agricultural Experiment Station. 


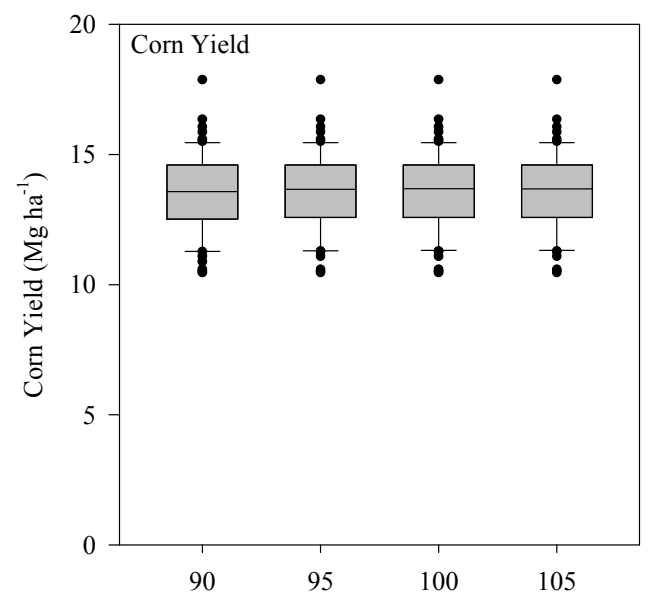

Late Season Irrigation Termination DAP

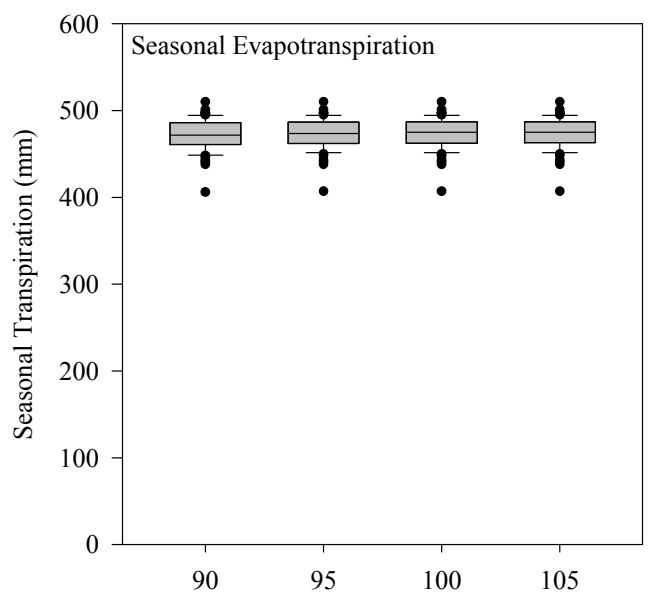

Late Season Irrigation Termination DAP

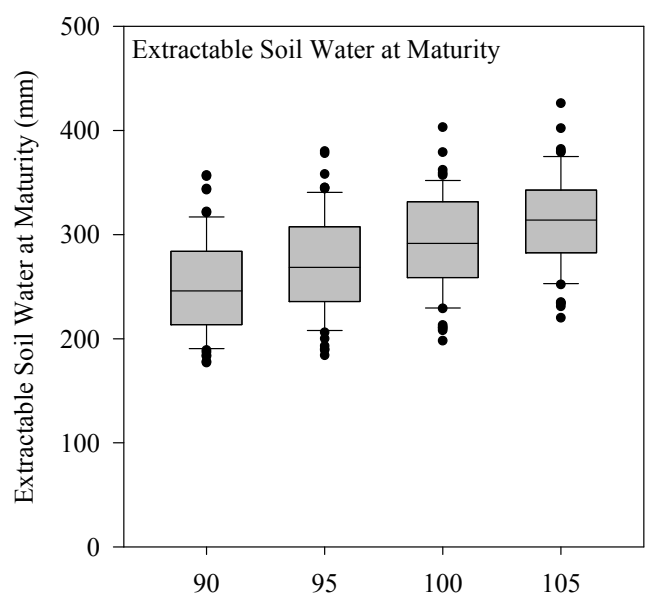

Late Season Irrigation Termination DAP

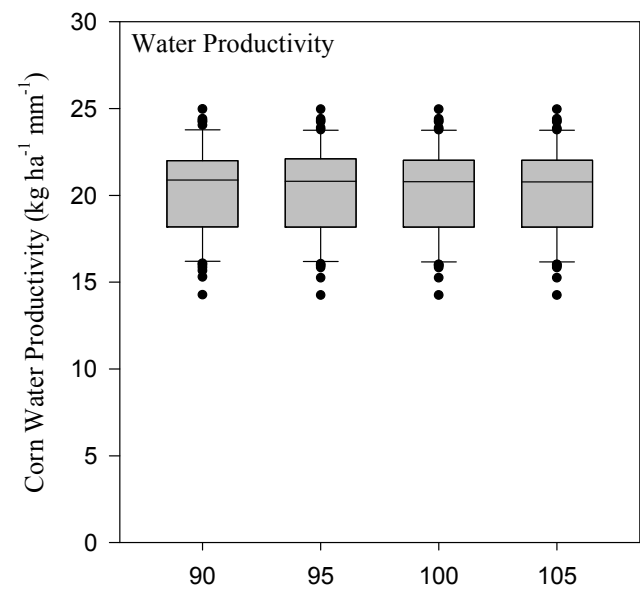

Late Season Irrigation Termination DAP

Figure 9. Uncertainty in corn yields, extractable soil water at physiological maturity, seasonal transpiration, and water productivity associated with late season irrigation termination at SWREC near Garden City, Kansas. Black dots represent outliers or values greater than 1.5 interquartile ranges away from the 25 th or 75 th percentiles.

\section{REFERENCES}

DeJonge, K. C., Andales, A. A., Ascough, J. C., \& Hansen, N. C. (2011). Modeling of full and limited irrigation scenarios for corn in a semiarid environment. Trans. ASABE, 54(2), 481-492. http://dx.doi.org/10.13031/2013.36451.

DeJonge, K. C., Ascough, J. C., Andales, A. A., Hansen, N. C., Garcia, L. A., \& Arabi, M. (2012). Improving evapotranspiration simulations in the CERES-Maize model under limited irrigation. Agric. Water Mgmt., 115, 92-103. http://dx.doi.org/10.1016/j.agwat.2012.08.013.

Dhuyvetter, K. C., O’Brien, D. M., Haag, L., \& Holman, J. (2014). Center-pivot irrigated corn cost-return budget in western Kansas. Farm Management Guide MF8. Manhattan, Kans.: Kansas State University Agricultural Experiment Station and Cooperative Extension Service. Retrieved from www.ksre.ksu.edu/bookstore/pubs/mf585.pdf.

Dixon, P. M., Weiner, J., Mitchell-Olds, T., \& Woodley, R. (1987). Bootstrapping the Gini coefficient of inequality. Ecology, 68(5), 1548-1551.

Guerrero, B. A., \& McCollum, T. (2013). The impact of the beef industry in the southern Ogallala region. AG 001 College Station, Tex.: Texas A\&M AgriLife Extension.

Heeren, D. M., Trooien, T. P., Werner, H. D., \& Klocke, N. L. (2011). Development of deficit irrigation strategies for corn using a yield ratio model. Appl. Eng. Agric., 27(4), 605-614. http://dx.doi.org/10.13031/2013.38207.

Jones, C. A., \& Kiniry, J. R. (1986). CERES-Maize: A Simulation Model of Maize Growth and Development. College Station, Tex.: Texas A\&M University Press.

Jones, J. W., Hoogenboom, G., Porter, C. H., Boote, K. J., Batchelor, W. D., Hunt, L. A., Wilkens, P. W., Singh, U., Gijsman, A. J., \& Ritchie, J. T. (2003). The DSSAT cropping system model. European J. Agron., 18(3-4), 235-265. http://dx.doi.org/10.1016/S1161-0301(02)00107-7.

Keating, B. A., Carberry, P. S., Hammer, G. L., Probert, M. E., Robertson, M. J., Holzworth, D., Huth, N. I., Hargreaves, J. N. G., Meinke, H., Hochman, Z., McLean, G., Verburg, K., Snow, V., Dimes, J. P., Silburn, M., Wang, E., Brown, S., Bristow, K. L., Asseng, S., Chapman, S., McCown, R. L., Freebairn, D. M., \& Smith, C. J. (2003). An overview of APSIM, a model designed for farming systems simulation. European J. Agron., 18(3-4), 267-288. http://dx.doi.org/10.1016/S11610301(02)00108-9.

Klocke, N. L., Hunter Jr., C., \& Alam, M. (2003). Application of a linear-move sprinkler system for limited irrigation research. ASAE Paper No. 032012. St. Joseph, Mich.: ASAE.

Klocke, N. L., Currie, R. S., Tomsicek, D. J., \& Koehn, J. (2011). Corn yield response to deficit irrigation. Trans. ASABE, 54(3), 931-940. http://dx.doi.org/10.13031/2013.37118.

Klocke, N., Currie, R. S., Kisekka, I., \& Stone, L. R. (2014). Corn 
and grain sorghum response to limited irrigation, drought, and hail. Appl. Eng. Agric. 30(6), 915-924.

Lamm, F. R., \& Aboukheira, A. A. (2009). Corn irrigation macromanagement at the seasonal boundaries: Initiating and terminating the irrigation season. In Proc. Central Plains Irrigation Conf. (pp. 40-60). Colby, Kans.: Central Plains Irrigation Association.

Lamm, F. R., Rogers, D. H., \& Clark, G. A. (1996). Irrigation scheduling for corn: Macromanagement. In Proc. Evapotranspiration and Irrigation Scheduling Conf. (pp. 741748). St. Joseph, Mich.: ASAE.

Lamm, F. R., Stone, L. R., \& O’Brien, D. M. (2007). Crop production and economics in northwest Kansas as related to irrigation capacity. Appl. Eng. Agric., 23(6), 737-745. http://dx.doi.org/10.13031/2013.24057.

Lamm, F., Rogers, D. H., Schlegel, A. J., Klocke, N. L., Stone, L. R., Aiken, R. M., \& Shaw, K. L. (2012). Assessment of plantavailable soil water on producer fields in western Kansas. In Proc. 24th Annual Central Plains Irrigation Conf. (pp. 37-50). Colby, Kans.: Central Plains Irrigation Association.

Ma, L., Nielsen, D. C., Ahuja, L. R., Malone, R. W., Saseendran, S. A., Rojas, K. W., Hanson, J. D., \& Benjamin, J. G. (2003). Evaluation of RZWQM under varying irrigation levels in eastern Colorado. Trans. ASAE, 46(1), 39-49. http://dx.doi.org/10.13031/2013.12547.

McGuire, V. L. (2012). Water-level and storage changes in the High Plains aquifer, predevelopment to 2011 and 2009-11. USGS Scientific Investigations Report 2012-5291. Reston, Va.: U.S. Geological Survey.

Musick, J. T., \& Lamm, F. R. (1990). Preplant irrigation in the central and southern High Plains. Trans. ASAE, 33(6), 18341842. http://dx.doi.org/10.13031/2013.31547.

Raes, D., Steduto, P., Hsiao, T. C., \& Fereres, E. (2009). AquaCrop: The FAO crop model to simulate yield response to water: II. Main algorithms and software description. Agron. J., 101(3), 438-447.

Ritchie, J. T. (1998). Soil water balance and plant water stress. In G. Y. Tsuji, G. Hoogenboom, \& P. K. Thorton (Eds.), Understanding Options for Agricultural Production (pp. 41-54). Dordrecht, The Netherlands: Kluwer Academic.

Rogers, D. H. (2007). Irrigation. In Corn Production Handbook (pp. 30-36). Manhattan, Kans.: Kansas State University Agricultural Experiment Station and Cooperative Extension Service. Retrieved from www.bookstore.ksre.ksu.edu/pubs/c560.pdf.

Rogers, D. H., \& Lamm, F. R. (1994). Soil water survey after corn harvest in northwest Kansas. Appl. Eng. Agric., 10(1), 37-40. http://dx.doi.org/10.13031/2013.25824.

Saseendran, S. A., Ahuja, L. R., Nielsen, D. C., Trout, T. J., \& Ma,
L. (2008). Use of crop simulation models to evaluate limited irrigation management options for corn in a semiarid environment. Water Resour. Res., 44(7), W00E02 http://dx.doi.org/10.1029/2007WR006181.

Schlegel, A., Stone, L., Dumler, T., \& Lamm, F. (2011). Preseason irrigation of corn with diminished well capacities. In Proc. 23rd Annual Central Plains Irrigation Conf. (pp. 11-18). Colby, Kans.: Central Plains Irrigation Association.

Schneekloth, J. P., Kaan, D. A., \& Pritchett, J. (2004). Determining crop mixes for limited irrigation. In Proc. 2004 Central Plains Irrigation Short Course Exposition (pp. 45-52). Colby, Kans.: Central Plains Irrigation Association.

Soltani, A., \& Hoogenboom, G. (2003). Minimum data requirements for parameter estimation of stochastic weather generators. Climate Research, 25(2), 109-119. http://dx.doi.org/10.3354/cr025109.

Stone, L. R., Schlegel, A. J., Khan, A. H., Klocke, N. L., \& Aiken, R. M. (2006a). Water supply: Yield relationships developed for study of water management. J. Nat. Resources Life Sci. Educ., 35(1), 161-173.

Stone, L. R., \& Schlegel, A. J. (2006b). Crop water use in limitedirrigation environments. In Proc. 2006 Central Plains Irrigation Conf. (pp. 173-184). Colby, Kans.: Central Plains Irrigation Association.

Thornton, P. K., Wilkens, P. W., Hoogenboom, G., \& Jones, J. W. (1994). Sequence analysis. In G. Tsuji, G. Uehara, \& S. Balas (Eds.), DSSAT v3, Vol. 3. Honolulu, Hawaii: University of Hawaii.

Todorovic, M., Albrizio, R., Zivotic, L., Abi Saab, M., Stöckle, C., \& Steduto, P. (2009). Assessment of AquaCrop, CropSyst, and WOFOST models in the simulation of sunflower growth under different water regimes. Agron. J., 101(3), 509-521. http://dx.doi.org/10.2134/agronj2008.0166s.

Tsuji, G. Y., Uehara, G., \& Balas, S. (Eds.) (1994). Decision Support System for Agrotechnology Transfer (DSSAT) Version 3. Honolulu, Hawaii: University of Hawaii.

Tsuji, G. Y., Hoogenboom, G., \& Thornton, P. K. (Eds.) (1998). Understanding Options for Agricultural Production. Systems Approaches for Sustainable Agricultural Development, Vol. 7. Dordrecht, The Netherlands: Kluwer Academic. http://dx.doi.org/10.1007/978-94-017-3624-4.

USDA-ARS. (1992). Root Zone Water Quality Model, Version 1.0, Technical Documentation. GPSR Technical Report No. 2. Fort Collins, Colo.: USDA-ARS Great Plains System Research.

Van Diepen, C. A., Wolf, J., van Keulen, H., \& Rappoldt, C. (1989). WOFOST: A simulation model of crop production. Soil Use Mgmt., 5(1), 16-24. http://dx.doi.org/10.1111/j.14752743.1989.tb00755.x. 